\title{
Becoming Witches: Sight, Sin, and Social Change in the Eastern Highlands of Papua New Guinea
}

\author{
Thomas Strong
}

\section{INTRODUCTION}

The Bible talk was about the fourth chapter of Genesis. A story every Christian knows. The brothers Cain and Abel made offerings to God. The elder, Cain, was a farmer and he offered some of his crops. Abel was a shepherd and offered a lamb. But God was displeased with Cain's sacrifice, provoking anger and humiliation. Cain killed his brother in jealousy. Retelling a classic story, the pastor asked us: why had God rejected Cain's gift?

We were in the United Pentecostal Church in Dudumia village in the upper Asaro valley of Papua New Guinea's eastern highlands. The United Pentecostal Church is one of the several Pentecostal congregations in the area, alongside Revival Centres International and the PNG Revival Church. As with Pentecostal services everywhere, that Sunday morning was meant to feel unscripted, characterized by spontaneity and inspiration rather than formal routine. Congregants were drawn

T. Strong $(\square)$

Maynooth University, Maynooth, Ireland

(C) The Author(s) 2017

K. Rio et al. (eds.), Pentecostalism and Witchcraft, Contemporary Anthropology of Religion, DOI 10.1007/978-3-319-56068-7_3 
from the various villages of the upper Asaro; some had walked for an hour or more to attend. Men wore their best trousers and shoes, if they had them; women wore colorful blouses and laplaps. The social space beneath the corrugated tin roof was divided by a notional aisle dividing the cement floor into separate sections for men and women. In the front of the church, behind the altar, appeared two images: the logo of the United Pentecostal Church International-a grid of the latitudinal and longitudinal lines of the globe circled by the words "The Whole Gospel to the Whole World," with the address for the Church's headquarters in Hazelwood, Missouri underneath — and a poster with photographs of the American couples assigned to oversee the Church's missions around the world. We were in a high mountain valley in New Guinea contemplating themes of global, universal significance.

The man who held the podium that day wanted to know: why did God look unfavorably upon Cain?

God wanted them to show themselves, their hearts, to him (olsem bel bilong tupela, tupela soim em). Because there was some bad feeling there, there in Cain's body. Some bad feeling toward his brother. There were some 'motives' (in English) there. So this offering Cain made to God, it didn't sit well with God (em $i$ no go tru long bigpela). The offer wasn't straight. However, the sacrifice of Abel was good. God accepted his offering because God looked ...

And here he paused. "God doesn't just see your body when he observes you. When God looks at you what does he see? What does Samuel 16:7 say? What does he see?" The congregation replied: "Spirit." The sermon continued:

Your spirit! He sees your heart ( $b e l$ )! If I look at you, I just see your face. But God, he gazes (glasim) inside. How much you love him, how much you love him. Do you love him half-heartedly? God weighs you up (skelim) as he observes you. Are you hiding something behind your back? Or in some other corner of your person ( hap kona)? God, he knows. People hide things, but in the eye of God you are so clear. What does Hebrews 4:13 say? Everything is open to him and he sees.

Each Christian life is like an offering to the Lord, he continued: "A sacrifice." But each person must offer himself to the Lord as a whole person 
and with a pure heart; one should not hold back any part of the self. Referring to Isaiah 6:4-8, he proclaimed:

You must be cleansed by the fire of the Holy Spirit. We must place ourselves on the fire of the Lord and he must purify (kukim) us: each part of us. Our whole body. Our hair, our mouths, everything. Without this there is no heaven. You must remove these bad ways from yourself. What must you do?

Congregation: Defeat sin.

Whoever wronged you, or did something bad to you, or stole from you, or wronged your family - you can't hold on to this 'backside thinking' or this 'bad feeling' (tingting nogut) about them. Because then to God you would be giving a bad offering. Cain harbored bad feelings about his brother, jealousy or envy, and so he gave what kind of offering? A spoiled one. We can't hide. Our minds (tingting), our hearts (bel), they must always be open and entirely free. We must defeat sin. As it says in 1 John 3:15: If you resent your brother (bel nogut), what do you do to him?

Congregation: Kill him.

If I resent my own brother Stephen, I kill him! I may not physically kill him, but in spirit, I murder him. This is hidden sin. It's 'secret' sin, 'unseen' (in English) sin, right? We can't see it with our eyes: other people can't see this. Only you. And God.

In the upper Asaro valley, people live in fear of what is hidden in each other and indeed in themselves. Though the Bible story relates that Cain killed Abel after God's rejection of his sacrifice, the sermon located Cain's failing earlier in the tale: in the hidden resentment that rendered his sacrifice ruined, poisoned. This poison, the pastor warned, must be removed from people offering their souls to God. But the sermon contained another meaning that I only realized afterward-a warning about witchcraft (gwumu, sanguma).

Gwumu witches see inside persons, their victims, but conceal themselves from sight. The invisibility of witches makes possible an occult realm existing in parallel to everyday life, another "side," endangering people's vitality, growth, and relationships. Evangelical and Pentecostal sermons often focus on these dynamics of in/visibility. Christian piety, for example, is evinced as a shine on the body that deflects the covetous and hungry gaze of witches. Congregation members are said to 
be covered by the blood of Christ; only those who attend church will enjoy the protection that God's grace affords. In 2014, a Baptist preacher described witchcraft to me as a "wildfire" in the valley, threatening the patrimony of both clan and country, dimming peoples' hopes for future development, and robbing the country of the little wealth it had. Frequently during my fieldwork, my informants told me that the very land they lived on was "cursed." Christian discourse, and especially Pentecostal emphasis on "evil spirits" (spirit nogut), simultaneously speaks to and elicits fears of this "curse" of witches, and offers a solution: redemption through the church.

This chapter explores relationships among constructs of sin and sight, the "heathen" and the hidden, in the PNG highlands. Beginning in 1998 and continuing with several return visits through 2014, I conducted fieldwork with people who perceive themselves as plagued both by witchcraft and by the attempts of youth to "mobilize" (mobilais) against suspected witches through violent and sometimes deadly witch hunts (Jorgensen 2014). My analytical focus on sight is motivated by two connections. The first pertains specifically to how people talk about witchcraft. Much of the discourse on witchcraft revolves around dynamics of "in/visibility." Witches remain hidden, yet evidence of their presence is everywhere: in sickness and death, in poverty and lack of development, in portentous world events and an overall feeling that the end times, the apocalypse, is upon us. Though themselves mainly invisible, witches are gifted with special powers of sight, provoking them to covet the vitality and value they spy in other persons and enabling a perspective that discloses a modern world only they can see. Witchcraft discourse, then, dwells on problems of vision and value, gazing and greediness, even as it evokes an invisible world of material bounty obtained through malicious influence. These paradoxes of perception articulate witchcraft idioms with those characteristic of Pentecostal and charismatic Christianity that speak of individual redemption and piety in terms of the shielding white light of God's grace.

The second connection motivating a focus on the sense of sight relates to its importance in local concepts of power, order, and moral comportment. Deliberate acts of concealment and revelation are associated with power, especially in its distinctive Melanesian manifestations as vitality (growth) and value (wealth) in persons (Strathern 2013). At the same time, materializations of such power, in beauty and bounty, may engender feelings of resentment and jealousy in witnesses. Such 
incipient inequalities are troubling to people committed to an axiomatic Melanesian moral ethos of egalitarianism. Wealth exchange (e.g., Strathern 1975; Munn 1992) has been analyzed as both manifesting and mediating a Melanesian cultural tension between equality and competition, between autonomy and relationality (Read 1955). Today, this tension is catalyzed by an economic scene of growing inequality between persons and between places, as, for example, the inequality felt between those who inhabit towns and live on money and those thought to be left behind in villages and gardens. Thus, if the sociality of sight has been an important analytic in the ethnography of Melanesia, it becomes especially salient in a discussion of witchcraft and Christianity in Papua New Guinea today. Below, I first situate the upper Asaro ethnographically, before proceeding to a discussion of sin, sight, and sociality as these are informed by Melanesian cultural dynamics. Highlighting the theme of sight allows us to pinpoint areas of articulation between Pentecostal Christianity and the powers of contemporary witchcraft.

\section{Who Is Blocking the RoAd to Development?}

The Dano-speakers (Strange 1965) of the upper Asaro live in nucleated villages composed largely of small round grass houses. Villages are most often constituted by an exogamous, patrilineal clan, and social structural segmentation - as between clan, subclan, and the units of which they are comprised such as lineages - is usually isomorphic with residential patterns; lineage members tend to cluster within villages. Affinal, matrilateral, and sororal ties create an important matrix of "kindred" (kandere) extending beyond the agnatic clan, creating relational resources and obligations that always exist in tandem and in tension with the dominant patrilineal order. The relation between clan and kindred is the principle focus of the ceremonial exchange practices accompanying events such as birth, puberty, marriage, and death.

The valley floor, which rises from about $1800 \mathrm{~m}$, is overlain with a patchwork quilt of abundant, well-tended gardens, as well as the remains of large multihectare plantations that were established prior to independence but have since been abandoned and mostly reclaimed by smallholder coffee growers (Strong 2006; Downs 1986). People supplement the staple crop sweet potato with many other crops (taro, corn, beans, peanut, oranges, avocado, coffee, and so on), and fresh vegetable marketing is today a lucrative source of income (Benediktsson 2002). People 
also consume store-bought goods like cooking oil, rice, or ramen noodles that they usually acquire in Goroka town, the provincial capital, about an hour away on the back of a flatbed truck. Pigs and cooked pork are the most prestigious wealth items in ceremonial exchanges, though those exchanges also always involve state currency often ritually displayed on bamboo poles sometimes referred to as "money trees." Parents spend their days tending to gardens while their children attend local schools, and in the evenings, generator-powered "video houses" provide entertainment for villagers, who may also recharge their mobile phones in them.

Lutheran, Seventh Day Adventist, and Catholic missions began successfully to convert people in the upper Asaro to varieties of Christian practice around 1950, arriving in the immediate vicinity of my field site in the 1960s. People today are enthusiastically Christian, and attend Evangelical Brotherhood, Revival Centres International, Assemblies of God, SDA, Mormon, Four Square, Salvation Army, Pentecostal, Baptist, and Catholic churches.

Since I began fieldwork, Papua New Guinea has witnessed precipitous social change. The commodities boom of the 2000s, especially in the Pacific Rim, impacted PNG dramatically. Foreign investment in the country has risen, mainly in the area of natural resource extraction. A massive Exxon Mobil-operated liquid natural gas project in the Southern Highlands began piping petroleum out of fields in the southwest highlands in 2014. Some of my informants have found employment in these fields, and though dreams of natural resource wealth figure significantly in how people imagine the future for themselves and their country (Golub 2014; Jacka 2015), grassroots economic benefits of such large scale projects are rarely seen (Kirsch 2014). The project, "PNG LNG," literally doubled the GDP of the country in 2015, the 40th anniversary of national independence. Many people interpreted this event in Biblical terms: PNG would finally emerge from its 40 -year "trial" of independence to become a resource-rich leader of Pacific Islands nations.

The State has grown almost entirely dependent on natural resource extraction and exploitation for revenue (Kirsch 2014; Lattas and Rio 2011). Newly rich Papua New Guineans, whether politicians, public servants, businessmen, or those heir to a tribal (petrochemical) patrimony, are dramatically driving up real estate prices, and prices of CocaCola and frozen chickens, in the major towns. The 'Real Estate' section of the Post-Courier, a News Corporation-owned concern, features 
advertisements for gated estates in Cairns and Brisbane, from which Virgin Australia now operates two daily departures to Port Moresby.

This boom, already now historical with the global collapse of petroleum prices, created both pathways of opportunity and potholes of deprivation, as does the hopping and skipping of global capital everywhere (Ferguson 2006). While resource-rich areas benefit from new roads and other infrastructure, the people of the upper Asaro believe they have been "left behind," or worse, are "reversing back" and losing even the services once associated with the colonial plantation economy. Two nostalgias can be identified in frustrated commentary on this situation: one for lost vitality - as when people say that the ancient ancestors were physically much stronger and bigger than people are now (Strong 2007) — and another for the ostensibly more productive colonial social order and the development it brought to the valley in the twentieth century. As people search for reasons why the blessings of modernity have been persistently withheld from those in the village, nefarious, invisible witches are increasingly blamed for "blocking" the road to development and material wealth.

If witchcraft is a problem many Papua New Guineans see themselves sharing in common, in national and elite discourse on mystical violence locally distinctive types of witchcraft and sorcery are sometimes confused. Arguably deriving from the imposition of a generic category"the spiritual"-upon a diverse set of ideas and actions, NGO and legal discourse refers most frequently simply to "sorcery" and "sorceryrelated killings" or "SRK." Yet often there are locally salient distinctions between sorcery as an instrumental technique for harming others, often used by people who also acquire techniques of healing and divination, and witchcraft as an innate or unlearned propensity to carry out invisible violence. Evans-Pritchard's old (1937) dichotomy accurately captures an important distinction salient in many parts of $\mathrm{PNG}$, but especially in the Eastern Highlands: the sorcerer may be feared and stigmatized by his dabbling in the diabolical, but he may also be respected (cf. Lindenbaum 1979; Godelier 1986) — whereas the witch is always regarded as purely malevolent (Stephen 1987a, b). My ethnographic focus here is on ideas about witchcraft specifically characteristic of the central PNG highlands, and in particular what has become known as kumo witchcraft (I follow the Dano orthography of Newman $(1964,1965)$ in rendering this word as gwumu). 
Even as diverse ideas about witchcraft and sorcery are found across the country, PNG national culture is increasingly occupied by a common set of Christian ideas and symbols, especially those of evangelical, charismatic, or Pentecostal varieties. These ideas and symbols are strongly characterized by a theology of "spiritual warfare" found in Pentecostal and charismatic Christian teaching (Jorgensen 2014; Schram 2014; Robbins 2004b; Wesch 2007). This framework envisions recent PNG history as a rupture with a tradition that must be repudiated as demonic: symbols and ideas associated with traditional or customary pasts become associated with Satan, who must be overcome in a manichean struggle between forces of 'good' (Christianity) and 'evil' (tradition; compare especially Meyer 1999). This process of resignification sits uncomfortably alongside discourse that enlogizes the loss of the cultural practices of which Pentecostal Christianity demands repudiation, creating scenes of sharp contestation between an ethos of nostalgia for traditional pasts and an aspirational ethos of hope for a different future. Perhaps the most emblematic example of the tensions generated by an ascendant equation of PNG nationality with Christianity came in 2013 when the Speaker of Parliament attempted to purify and sanctify Port Moresby's Parliament House by destroying special carvings originally intended to emblematize PNG pride in its customs, but now seen by some Christians as retaining the presence of the demonic (the traditional) in the very seat of national power (Schram 2014, see also Introduction, this volume). Christian repudiation of the symbolism of traditional culture also occurs in provinces and in villages (Tuzin 1997). In the Eastern Highlands Province, for example, the traditional figure of nokondi on the provincial emblem and flag has long been suspected to inhibit the province's development because of its association with traditional beliefs, that is, with the demonic. Nokondi is a spiritual mischief-maker found across the eastern highlands (Lindenbaum 2002), and people in the Eastern Highlands frequently decorate themselves as nokondi-like figures for regional cultural festivals. Yet people speculate that nokondi's presence in the official iconography of the provincial government has exerted a malicious influence over the region. During a National Prayer Day event in Goroka in 2013, Prime Minister Peter O'Neil joined Governor Julie Soso in honoring the "Covenant of the People of Papua New Guinea with the People of Israel" (see Newland and Brown 2015). Afterwards, approving talk circulated that Soso had officially decreed that nokondi was to be removed from all provincial 
insignia. This attempted erasure of a symbol simultaneously thought to signify "tradition" and to manifest the demonic was reminiscent of events occurring decades earlier, when most villages in the eastern highlands were subject to the public exposure and destruction of secret or esoteric ritual artifacts (such as sacred flutes) as part of missionary programs of "collective conversion" of villagers (Smith 1979).

This framework, which reinterprets symbols of indigenous religion as signs of a Christian struggle between good and evil, layers moral value over historical rupture (Robbins 2004a, b). Symbols of the (traditional) past are taken to represent and realize an evil that must be overcome, whereas Christian symbols point to future redemption (Bashkow 2000a; see also Eriksen and Rio, this volume). Thus, a further aspect of this national Christian culture is eschatological discourse that forms the dominant mode of contemporary historical interpretation both on the national scene and in villages, as people read news and events for signs portending the inevitable return of Christ. In the Asaro region then, the "curse" of witches overtaking village and valley is consistently interpreted as indicating that PNG and the world more broadly have entered into the "bad times," taim nogut - the apocalypse.

Although my recent fieldwork focus was on the Evangelical Brotherhood Church (EBC) and United Pentecostal Church, I mainly attended a local Baptist congregation in 1998, 2000-2001, and 2003. Each of these denominations has distinctive doctrinal precepts and ritual practices. The EBC has a decades-long history in the valley and is associated with a Swiss mission and an important health center and aid post about an hour walk from the village in which I do fieldwork. Pentecostal churches are much newer arrivals on the scene. Older Lutheran, Catholic, Baptist, and Seventh Day Adventist congregations are important institutions in the valley and the eastern highlands more generally. But the arrival of new churches occasions considerable interdenominational criticism, contestation, and conflict, particularly between the adherents of the mainline older congregations and those of the newer charismatic variety (Handman 2014; Jebens 2005). Lutheranism, in particular, is associated with older generations and even with the tumbuna (ancestors) comprising the first generation to have converted to Christianity in the years following World War II. Indeed, youth today often reject older congregations as remnants of a traditional social order needing reform; the historical rupture that Christian conversion creates between "old" and "new," figured in this discourse as a generational 
conflict, is recreated in the present as a contest between styles of Christian devotion. For example, male evangelical youth sometimes entertain diabolical fantasies about satanic rituals and infant sacrifices occurring beneath the largest Catholic churches in the eastern highlands.

Nevertheless, some common Christian themes inflect local talk of all kinds, such as how recent history is interpreted or specific village misfortunes are understood. Particularly in connection with witchcraft, a generalized Christian culture is the most important lens through which people view their circumstances. A potent image sums up this culture: the image of the blood of Christ covering the devout and protecting them from the invasive gaze of jealous witches.

\section{“The Witches Are Professionalizing"}

Ideas about witchcraft in the upper Asaro valley dwell on problems of visibility and violence, dilemmas of sight and sociality, in many ways. Here is Virikare, a young man who grew up in Port Moresby but who for the last few years has lived in the village:

My brothers have shown me the list of witches. Some of the family members I have stayed with, they are a witch family. But ... I don't say to myself: "Ah, This is a witch family, I'm afraid, I'll run away." Because in fact all the time there will be witches: so who would I stay with? Who is a good man with whom I would stay? They are all witches. So I just bow my head and go around. I'm hungry, I go to the house and eat. I don't worry too much ... I know God is watching, and if they want to do something bad to me, or something good to me, I don't mind. It's true that the village is full of witches.

\section{T: So you heard that in Moresby too?}

In Moresby, they told me all about it. It's a big story. When my brother came down to Moresby to be a security guard, he said: don't go back to the village. It's full of witches. But I grew up in Moresby, and I was tired of it. ... So I wanted to come here to see the life in the village, the situation - and then return to the city. It's true, the village is full of witches. Really, no one is innocent. Even babies - when they give the babies milk, they give them witchcraft (sanguma). When the babies grow, they are taken to the cave at Owia stone ... They go to the stone, and file their teeth and when they see that they are sharp, then they know that the child is ready. They can eat people now ... kill people ... destroy people. From 
the time they are babies they are prepared .... Now many of the little children - they are witches. But you can't tell ....

Our leaders too are witches. So when it comes to killing the witches, the leaders defend them. Say one witch attacks some other person. So the young men think about attacking or killing this witch. They think of ... capturing it and putting it inside a house. They will tell this witch: "Call out the names of all the witches." They will threaten the witch with a knife, use a hot wire and shoot the witches arms and legs with it, or whatever. The witch will suffer and feel pain, the witch will confess or 'talk out.' He will confess: "this man is a witch, this woman is a witch, this child is a witch." Or the witch can call out the name of a whole family, "they are all witches from mother to father to child." He will call out the other names, saying "them also, and them also." But some of the leaders in league with witches, they will be afraid... that a witch will reveal themselves also as witches. Because the leader didn't stop the young men from attacking the witch, so the witch will say this leader too is a witch. So the leader will try his best to defend the accused person. So our leaders too, they are witches! Plenty of times when the youth 'mobilize' in order to attack the witches, they'll say: "don't kill the witches! Let them be and just exile them." And when the young men hear this kind of talk, they'll say: “... You defend the witches, it means you are a witch also." Even if you are a 'good man,' they'll attack you.

They don't like the older men to control the village. Our mothers and fathers, they are "before line," they hold the way of the ancestors, such as witchcraft, "custom." Our new generation, we are born in the time of modern technology, the time of "computerized systems" .... This witchcraft practice, we don't know about it....If you oppose them, the youth, then you are a witch. So now, we young men we don't control the village. But now these young are saying, "we are tired of the old leaders - the traditional ( bifo) leaders... they will defend the witches, we young men will run this village." We need to get rid of these witches. They destroy our business and curse our gardens. The children aren't growing well either — the witches are preying on them. That's what the witches do. ... Their hidden thinking, their gut thinking, they don't want the good people to remain. They want it just to be a world of witches. So they are killing the good people. So this is the thinking of the young men - they are tired of the older generation of leaders.

The lives of witches have changed. They've developed. They've developed. Their society has developed. Like America or Australia. On the "spirit side," ... they are capable of all this. They have airplanes... cars... ships. 
Now here we are, you and me, and we look at this house we are sitting in, and it's made of grass and bush. But ... in the eye of the witches, this village is something else altogether... a very nice place. There are buildings, and big stores, that kind of thing. They've already developed, on the spirit side. And we "normal" people, we look at this village and it isn't very good. It's bush. But for them, this village is good, it's a city. So when you talk about witches, they are everywhere.

Virikare's monologue vividly captures ways in which the discourse of witchcraft expresses interlinked concerns for people in the upper Asaro: the repudiation of tradition, intergenerational tensions, unequal relations between village and city, a hoped-for social transformation (development) that seems ever out of reach, and above all the idea that the village is cursed by witches, but also by conflict about what to do about them.

The basic premise of witchcraft in the upper Asaro is not unlike that found elsewhere in the world: some people are thought to be inhabited by a concealed or invisible spirit called gwumu in the local language and sanguma or spirit nogut (evil spirit) in the national lingua franca, Tok Pisin. These beings are sometimes referred to as "Satan's angels," evil spirits ruled by the angel cast out of heaven. Some say that these demons were first brought to the world through the medium of pigs, an interpretation of Mark 5:13, where Jesus exorcizes demons by first sending them into the body of pigs. These beings, when manifest as witchcraft, reside in the gut or under the armpit of person; they most often dwell in the uterus, lending discourse about witches a decidedly gendered aspect, though men may also be accused and possibly killed after an accusation. Gwumu are often thought to be passed from person to person, sometimes unwittingly in market transactions via the sale of betel nut or via the intermediary of pigs (as when sweet potatoes purchased from witches are fed to pigs, who then transmit witch substance to those who consume them). But transmission especially occurs as a kind of inheritance, as Virikare mentions, so that the children and relatives of witches are themselves often suspected of harboring gwumu, because witchcraft may be passed along through the commensality and care associated with kinship relations. Indeed, the children of accused witches are stigmatized and whole families struggle under a spoiled reputation or "bad name."

People describe gwumu as an agency hiding inside the body of another: it may be referred to as a "doll" for example, and an additional idiom I recorded referred to these familiars as "little sisters." Though 
gwumu are held to be concealed in the interior of persons, they may nevertheless sometimes be seen as apparitions, especially when they have left the body of a person to hunt. In 2013, I recorded many types of apparition that witches were said to manifest as they travel about, such as lions, goats, bears, or wild dogs. Most commonly, however, people say that gwumu take the form of small, quick, highly mobile creatures-bats, rats, birds, moths, grasshoppers, butterflies, cicadas, and other insects. During coercive witchcraft confessions, butterflies and bats are said to cluster close-by; coming into contact with one of these creatures threatens infection and sparks fear. A bat flying overhead at night may hush conversation around a fire, and a startling nighttime encounter with any animal might elicit a rumor about a nearby witch. Talk of witches sometimes prompts talk of other sinister beings at large. In 2000-2003, rumors of a drakula spread through the valley: a Tolai woman from elsewhere in PNG was said to have learned the secrets of drakula during her education in Australia. Gossip about witches and demons today freely incorporates imagery derived from Hollywood movies and when I inquired whether white people have witches (cf. Schram 2010; see also Pype, this volume), the answer usually referred to the vampires represented in Hollywood films. The emphasis on "blood sucking" in the idea of vampires has begun to inflect local Asaro constructs of witchcraft, as when young men emphasize the sharpened teeth of child witches. Indeed, one of my informants claimed that witchcraft has come from white peoplethough, as indicated by Virikare, most people would say that it is an indigenous ancestral inheritance.

Witches are figures of unmitigated hunger or greed. At night, they feed on the internal organs of persons or pigs, eating livers, hearts, lungs, and brains. They may feed on the recently deceased so participants in funerary proceedings are therefore suspicious of persons who loiter near grave sites. An intense and covetous gaze is a further sign of nefarious intent, as witches can see into the bodies of their victims.

In fact, the presence of gwumu inside persons fundamentally changes their perception of the world, allowing them to peer beyond conventional appearances or external reality. They may see through the skin to the human vitality embodied in organs and blood, stimulating hunger. And they may see through conventional appearances to the "spirit side" beneath: an invisible world inhabited by witches, but alveady developed. "You see a village," Virikare told me, "they see a city." Significant features of the scene of village life both disguise and reveal aspects of the 
"spirit side." People might point to a large tree: "there is the witch's office building." That particular tree, a dying eucalyptus, is believed to be inhabited by witches because lights (fireflies) are seen in it at night; the rhythmic buzzing of cicadas that live in it are building alarms. In this "office building," the witches have a blackboard where they deliberate on who to kill, and witches can mark the exact time of death of people. Two large trees located across each other on the main road leading to one village high up the valley are known as the "witches' gate," a kind of monumental arch "on the spirit side." A stone may be a bus stop for the witch's transports. On the spirit side of the village, there is also a leisure club and a disco.

Moreover, across the central highlands, it is well known that Mount Elimbari is the "parliament of the witches," suggesting that the world of the witches has a proper, modern, even bureaucratic government. Witches are said to keep books, to meet regularly keeping lists of future victims. Their society also observes norms of reciprocity and exchange characteristic of a proper moral sociality. While witches only kill their own kin, they are said to trade these victims between each other (cf. Newell 2007).

In this invisible modern world, witches are "professionalizing," people told me. They are "increasing their standard," improving their techniques and attending school and university. As "normal" people figure out ways to track witches, witches develop new ways to evade detection, to bewitch people more efficiently, quickly, and without leaving a mark or any evidence - for example, with one shot from the "witches' guns."

On the spirit side, witches also hold occupations that for villagers most represent a "changed" (senis)—modern-society. One informant said: "On the outside you may see a pipia man, a rubbish man, a man with no wealth and no social standing. But 'on the inside' this individual may be a salaried employee." One woman who was killed in 2012 was thought to be an "air hostess," on the spirit side, because of the flair for the style she exhibited in her everyday dress. Two men were said to be "lawyers" in the world of witches because in everyday village life they "talk a lot." Witches have their own police men, their own members of parliament, and so on.

Witches, in short, are already the people that Papua New Guineans would like to become. Against a background of rotting grass houses and unruly youth, witches inhabit a wealthy and ordered modernity. If they are feared and condemned, they are also figures of desire, for they embody 
the style of life that people seek for themselves. The kind of acquisitive and individualistic subjectivity the witch symbolizes is appealing to people, while also instilling fear. The mixture of desire and repulsion that witches provoke condenses the manifold moral quandaries that modernity generates into a potent and contradictory figure: the modern citizen-subject who is also a monster committing unspeakable acts of mystical violence.

\section{Apprehending The Witch}

Although witches inhabit an invisible world, the presence of witchcraft is ascertained through analysis of images and events both everyday and misfortunate. Men known as glasman in pidgin or lusuve in the local language, are people best thought of as seers, people who can divine the sources of illness or misfortune. Lusuve say that in recent years their influence is being pushed aside, especially due to evangelical and Pentecostal sermons condemning them. Today, far more important in the unfolding of witchcraft accusations are spirit mediums, people possessed by the ghosts of witch's victims who may reveal their mystical assailants during trance-like episodes. It seems significant that both mediums I have spoken to attend Pentecostal churches. Thus, traditional modes of divination and sacred authority are being displaced by newer Christian ideas. Nevertheless, lusuve and spirit mediums may intervene in particular instances of misfortune, especially when sickness and death are involved. In such circumstances, people inspect the social environment for signs of bad feeling. Crucially, in the Asaro valley, witches are thought to prey only upon their own kin (cf. Geschiere 2013). So when looking for hidden resentment, people look to their kin first. Did the deceased give money to some kin but not others? Was a pig consumed that wasn't shared? Every accusation I have encountered revolves around the breaking of the ethos of reciprocity among kin.

Ultimately, however, misfortune itself is held to be the sign-the index (cf. Blanes, this volume) - of witchcraft. So the apperception of witchcraft in the world does not necessarily require the intervention of a medium or a diviner, and the ideas described here are drawn mostly from everyday conversations I had with people outside the context of any particular accusation. People speak frequently of the "curse" of witches. They point to their own apparent inability to develop socioeconomically and secure the promises of modernity as evidence that witches are 
stealing from them. Moreover, forms of premillennial dispensationalism script local misfortunes and worries into apocalyptic narratives about the end of times. Local affairs evoke momentous developments on the world stage, so that, for example, the arrival of a new mobile phone tower in the mountains above the village is taken to represent the advent of a One World Government, an important notion in this type of thinking, since the tower is held to be controlled from within the new World Trade Center building in New York City.

The curse of witchcraft consists in what witches do and the kinds of harms they produce. Witches consume vitality resulting in sickness and death. But they also steal value: people blame witches for failed business enterprises or the breakdown of a truck. Several people told me how witches "eat" the "value" (valu) of money, so that while an individual may think he or she has accumulated a certain amount of money, its value will be consumed by witches, and after spending the money a person will be left with nothing. Witches leave behind only "shadow" (sado) money. Because the village is cursed by witchcraft, only those that go to town can succeed in business. As indicated in Virikare's comments, relations between "village" and "city" are a fundamental dimension of witchcraft discourse, as symbols of contrasting social orders, one associated with subsistence and the demands of reciprocity and the other with development and individualism. Finally, during election seasons, unsuccessful candidates accuse witches of stealing their votes.

So people speak frequently of mutations in life, labor, and law when they describe the effects of witchcraft on their communities: witches consume vitality, value, and votes. They insinuate themselves into the major forms of contemporary social reproduction: family, economy, and government. This image of a distorted modernity, in which the promises of social change are visible but out of reach, tempting but not tangible, bears comparing to anthropological accounts elsewhere in the world that analyze the relationship between unseen forces and visible wealth (Comaroff and Comaroff 1993; Ferguson 2006; Geschiere 1997). Newell's (2007) notion of "Pentecostal witchcraft" conjures a hybrid phenomenon-simultaneously traditional and modern-responding to these contemporary conditions of desire and transformation, and their attendant inequalities and conflicts. Both Pentecostal worship and ideas about witchcraft engage with problems of money and morality, power and politics, individual redemption and social obligation, in a world where futures are uncertain and where people feel buffeted by 
unfair fates. Insofar as it blames demonic forces for the scattershot distributions of good fortune, Pentecostal discourse imagines its congregants as locked in a "spiritual battle," warding off or exorcizing the agencies that thwart progress. Whether this battle requires them to repudiate the past or to abstain from an emerging future (Pype, this volume), the agonism itself joins people ever more closely to the thing that troubles them. Indeed, in the next section, I show how Pentecostal witchcrafta synthetic and complementary realm of malicious evils (witches) and protective pathways (churches)-demands that people search themselves for signs of the sin that turns into witchcraft. As MacCarthy describes for the Trobriands (this volume), witchcraft is a force hidden in the self, but made visible in the harms and depredations visited upon others. If "Pentecostal witchcraft," then, names the hybrid cultural imaginary of spiritual warfare, we might call "Pentecostal witches" those persons who newly imagine themselves as the subjects, indeed the very sites, of that battle. This imaginary figures a changing world, placing local struggles on a global scene, and inviting people to view their own personal conflicts and relations within a framework of universal, even mythical significance, as when a sermon finds in mundane feelings of resentment between siblings the seed of murderous malevolence with world historical consequence. In so doing, this imaginary queries the kind of people Pentecostals see themselves becoming.

\section{Hidden Sin: Cain and Abel as Parable}

In the Bible talk on Cain and Abel with which I opened this chapter, God was able to look past the body to the disposition of the spirit that animates people: there God saw that Cain was acting duplicitously and deceptively. The sermon argued that the presence of this hidden feeling in Cain explains both God's disfavor at his offering, and Cain's later murder of Abel. Pentecostal Christians distinctively emphasize "the spiritual" and the direct manifestation of the presence of the Holy Spirit. The Holy Spirit is visible most especially in the movement of the body in ways held to reveal its presence. This manifestation of the spiritual makes visible a wanbel (reconciled, agreed, peaceful) state indicating the alignment of the individual Christian subject (worshipper) with God (Street 2010; cf. Kelly-Hanku et al. 2014). Thus, Pentecostals often describe two types of Christian- "spirit Christian" (the truly devout) and "body Christians" (those too concerned about material things, those who do 
not truly "believe" or have "faith")—a sort of interdenominational pejorative that condemns doctrinal emphasis on outward ritual rather than inner belief (Keane 2007). The outer body should ideally reveal an inner "spirit body," as, for example, through the kinds of ecstatic experience often associated with Pentecostal religious fervor.

In contrast, sin is understood as hidden in the body. Sermons that focus on sin as hidden thinking or emotions are interpreted by people listening as themselves a form of veiled speech referring to a problem of great consequence in communities: witchcraft. Through notions of hidden resentment or unseen discord, this Christian discourse associates sin with the gwumu witchcraft I have described. Following the sermon on Cain and Abel, church members told me that the visiting preacher was referring to witchcraft by using a local metapragmatic category of talk called tok bokis (literally, "box talk," but usually referred to as "veiled speech") or gramiyi harekeneve ("hidden talk") in Dano. Ideas about hidden sin are extremely common in Pentecostal services and discourse, and the idioms in which hidden sin is described are frequently also associated with witchcraft. Sin is often described in the local language as hidden in the bilum ("netbag") of the self, where the word bilum (ro in Dano) also means uterus, the location in the body where gwumu lives. This is a gendered, but flexible, discourse, as some accusations are also made against men. Nevertheless, Sunday morning altar calls seemed to me to be directed mainly at women congregants; speakers might even turn toward the side of the church where women sit when discussing hidden sin.

Thus people increasingly understand Christian discourse about sin to be about witchcraft. As I realized this, the very common Pentecostal themes of interior "spirit" bodies, hidden bad feelings, and so on gained new resonance: these were themselves "hidden" speech referring to the witchcraft concealed in the congregation (cf. Newell 2007: 472).

Two dimensions of the Cain and Abel parable stand out in regard to it as a parable of witchcraft. First, the story involves both material exchange and resentment, and almost all explanations of specific witchcraft incidents involve resentment, envy, or jealousy in relation to reciprocal obligations. Notably, it is the hiddenness of witches that allows them to elude demands for sharing wealth, and therefore enables them to accumulate. Second, the story involves bad feeling between siblings, and witches in the upper Asaro attack only their own close kin. 
The message of many other sermons and commentary I recorded turned on these themes of interior/exterior, hidden/revealed, in emphasizing that God's grace alone affords protection from the invasive gaze of witches. Here is how one congregant described this phenomenon:

There is no safe place, only in the church will you find help. Em banis tru.

You must hide underneath the blood of Christ. (Bai yu hait insait long blut bilong Jisas.) Jesus shed his blood on the cross, and this blood has all the strength for protecting us.

There is no other road. Only Jesus will protect (banisim) us.

When witches confess, they say things like: "When we encounter people who follow Jesus, when we would like to get close to them, there is a light! A strong light! It reflects against our vision, and we can't get close to them."

We church-goers have asked the witches (sanguma), the people with demons (spirit nogut). And those people say: "we want to harm you, to consume your meat, to take out your heart, your brain, your body... but there is a white cloth (laplap) that covers you, either a white shroud (laplap), or blood, red blood, it covers you. And it makes it hard for us to see you. ... Those who don't go to church - that's our highway! It's easy to go inside and eat. We can look inside you, in any corner (insait long wanem hap) - if you ate sweet potato. We can see that! Suppose you ate chicken, we can see that too there. If you ate pig and came, we could see that too. That's the power of the witch."

They wouldn't know except that they have this demon (spirit nogut) that sees. They can see into your very gut. If you ate sweet potato, or rice, they see it.

But the witches ruin our vision so that we can't see them. When they walk around, talking to each other, they can close your eyes. This spirit of theirs, it clouds your eyesight. This is some kind of power they have. It's some kind of power. It's the power of Satan.

Here two important Christian idioms resonate. First, Christian piety manifests as "light" or "shine" in the body and person of the devout. Pious Christians, those who especially exhibit the presence of the Holy Spirit, are so bright they are like "mirrors": they reflect back the invasive gaze of the witch. Second, and similarly, people discuss the blood of Christ as offering protection from witches. While often used as a 
metaphor, where the blood of Christ symbolizes redemption from sin, it is often described by my informants in quite material and bodily terms as a veiling shroud that prevents witches from seeing inside a person. Rather than the interior of bodies, the witches will instead see only the blood of Christ. One might say that the blood of Christ on the exterior of the body is actually the interior of the Christian body being made exterior, a body being turned inside-out (Strathern 1979). All of these ideas evoke powerful Melanesian constructs linking power and persuasion to what can and cannot be seen, how people make themselves visible to one another, and how that visibility implicates people in moral relationships to each other.

\section{Conclusion: On Sight and Sociality, the Sinful AND THe SPIRITUAL}

Ethnographic discourse on Melanesia often associates ideas about vision and dynamics of display with concepts of growth, social efficacy, and the moral relationship that obtains between objects and observers, persons and perspectives. An important dimension of this analysis pertains to the qualities Melanesians attribute to the sense of sight itself, to seeing as a particular kind of act, and to the effects that seeing can have on a witnessing subject. Bashkow refers to these dynamics as an "interpersonal economy of sight." Witnessing inequalities in attractiveness, wealth, or health, provokes feelings of either pity or poverty depending on perspective. To rectify this imbalance, the morally appropriate response is the exchange of a gift that reestablishes mutual respect and recognition: "Until ... the feeling of imbalance is counteracted, the perception of imbalance has the potential to assume a negative form, jealousy, that may lead to destructive actions" (Bashkow 2006: 123).

In the upper Asaro, for example, resplendently decorated dancers sometimes must give gifts to those who witness them, gifts known as ho or sun, an idiom that emphasizes brightness as a quality of health and wealth that is experienced as a ray that pierces the being of the subject who sees it.

In a context where to be seen is to be drawn into an interpersonal economy of sight, growth or transformation is achieved through concealment or secrecy, lest desiring others demand transactions that diminish such growth. Opacity, concealment, enclosure, and secrecy are all linked 
to ideas about growth, whether we speak of vibrant vital energies of the high mountain forest, thickly concealed with vegetation (Biersack 1982), or if we are thinking of the deliberate secrecy or opacity associated with many ritual activities in Melanesia, including especially forms of male initiation that grew young boys into strong men by removing them from the sight of their mothers and others, as was the case in the upper Asaro and its male cult (Read 1952).

Dialectics of sight and sociality, display and domination, exhibition and egalitarianism, are key qualities of the happening of social life in Melanesia. Yet this ethnographic literature on the social effects of tactics of concealment and display has focused largely on the motivations and intentions of social actors, on their personal and political purposes. The problem of witchcraft, however, involves dynamics of the concealed or unseen in contexts where people might wish to see but cannot. In the discourse of witchcraft, we find ideas about those who deceive without being perceived, and people who feel watched but cannot witness. Witchcraft in an important sense is about the disruption of the interpersonal economy of sight.

During my interviews with lawyers, police, and legal experts in Port Moresby and Goroka in 2013 and 2014, witchcraft was often said to be a "spiritual problem." When asked to describe what they mean by "the spiritual," people refer to things which cannot be seen-the invisible (cf. Blanes, this volume). Witchcraft is believed to be an especially troubling phenomenon because it is both everywhere and unseen. For those in PNG's law and justice sector, then, it is a problem precisely because it cannot leave evidence in its wake, making it impossible to prosecute, and contributing to the sense that witchcraft is increasing. A further connotation of what is meant by "spiritual" refers to the spirits or souls of persons and the corruption therein. Law and justice sector discourse characterizing witchcraft as a "spiritual problem," then, is also a discourse that locates the best means of addressing witchcraft in those institutions that address the souls of persons: churches. Most PNG police, scholars and others with whom I have worked would agree that the solution to PNG's problem of witchcraft is ministry. Ministry alone is thought to be capable of redeeming the community. But the irony of "Pentecostal witchcraft" reemerges, for the ministry that might solve the social problem of witchcraft can only do so by finding it over and again in its congregations. 
Witches inhabit a hidden world of material wealth by clouding the vision of the kin with whom they might otherwise feel obligated to share that prosperity. If this form of hiddenness is morally condemned, indeed is the very symbol of evil, Christian ideas offer redemption as itself a protecting shroud of piety-blocking the supernatural sight of witches with the white light and red blood of Jesus. To protect oneself from the poisonous envy of the prying eyes of kin, one must expose oneself entirely to the eye of God. The Pentecostal subject exchanges the perspective of kinship, associated with mutual aid and reciprocity, for the perspective of God and the Holy Spirit, associated with purity and individual salvation (Robbins 2004a). Thus purified by the fire of the Holy Spirit, the pious Christian subject becomes a kind of mirror of or for God, aligning the internal spirit body with the outward body visible to others, shining bright.

These ideas themselves reflect each other insofar as they emphasize the power of concealment itself. Power is to be found in the evasion of the affects and obligations of others, especially kin. But viewed through the convex lens of morality, these ideas about sight, sociality, and sin invert the values they appear to reproduce. Whereas ideas about witchcraft proclaim jealousy to be an insidious and harmful feeling within kin relations, their covert effect is to assure that kin be attentive to each other-to recognize each other through the material transactions thought to manifest obligation and visible harmony. The overt Pentecostal vision of redemption requires that such thoughts in the self be purged, but their covert message is that by purging oneself of negative feelings toward others, one gains protection against those very feelings in others through the alignment of the individual self with God (Schram 2010). The covert morality of witchcraft requires wealth to be shared. The morality of Pentecostalism offers liberation from these obligations. This is a fitting moral vision in a context where people badly desire for themselves the material benefits of a modernity that continues to elude, to hide, from them.

The discourse of "Pentecostal witchcraft" affirms a world threatened by witchcraft, and it does so in a personal way. In addressing congregants as people harboring bad feelings toward their kin, it insists that they view themselves as subjects of this temptation. Purging bad feeling yields a kind of piety that allows people to conceal themselves from the envious gaze of others. That is to say, they make themselves invisible to witches, appropriating the very power of concealment that witches are thought to monopolize. The Pentecostal church and the world of witcheraft are thus 
reciprocal visions of the power entailed in disrupting the interpersonal economy of sight. Moreover, accepting the Pentecostal dispensation means acknowledging the $\sin$ in oneself in order to achieve redemption. But since sin is another name for witchcraft, becoming Pentecostal means first acknowledging the witch you already are.

\section{REFERENCES}

Bashkow, Ira. 2000. "Confusion, Native Skepticism, and Recurring Questions About the Year: 'Soft' Beliefs and Preparations for the Millennium in the Arapesh Region, Papua New Guinea.” Ethnohistory 47 (1): 133-169.

Bashkow, Ira. 2006. The Meaning of Whitemen. Chicago: University of Chicago Press.

Benediktsson, Karl. 2002. Harvesting Development: The Construction of Fresh Food Markets in Papua New Guinea. Ann Arbor: University of Michigan Press.

Biersack, Aletta. 1982. "Ginger Gardens for the Ginger Woman: Rites and Passages in a Melanesian Society." Man (N.S.) 17: 239-258.

Comaroff, Jean, and John Comaroff. 1993. Modernity and Its Malcontents: Ritual and Power in Postcolonial Africa. Chicago: University of Chicago Press.

Downs, Ian. 1986. The Last Mountain: A Life in Papua New Guinea. St. Lucia: University of Queensland Press.

Evans-Pritchard, E. E. 1937. Witchcraft, Oracles and Magic among the Azande. Oxford: Clarenden Press.

Ferguson, James. 2006. Global Shadows: Africa in the Neoliberal World Order. Durham: Duke University Press.

Geschiere, Peter. 1997. The Modernity of Witchcraft: Politics and the Occult in Postcolonial Africa. Charlottesville: University Press of Virginia.

Geschiere, Peter. 2013. Witchcraft, Intimacy, and Trust: Africa in Comparison. Chicago: University of Chicago Press.

Godelier, Maurice. 1986. The Making of Great Men: Male Domination and Power Among the New Guinea Baruya. Cambridge: Cambridge University Press.

Golub, Alex. 2014. Leviathans at the Gold Mine: Creating Indigenous and Corporate Actors in Papua New Guinea. Durham: Duke University Press.

Handman, Courtney. 2014. Critical Christianity: Translation and Denominational Conflict in Papua New Guinea. Berkeley: University of California Press.

Jebens, Holger. 2005. Pathways to Heaven: Contesting Mainline and Fundamentalist Christianity in Papua New Guinea. London: Berghahn Books. 
Keane, Webb. 2007. Christian Moderns: Freedom and Fetish in the Mission Encounter. Berkeley: University of California Press.

Kelly-Hanku, Angela, et al. 2014. "We call it a virus but I want to say it's the devil inside': Redemption, moral reform and relationships with God among people living with HIV in Papua New Guinea." Social Science and Medicine 119: 106-113.

Jacka, Jerry. 2015. Alchemy in the Rain Forest: Politics, Ecology, and Resilience in a New Guinea Mining Area. Durham: Duke University Press.

Jorgensen, Dan. 2014. "Preying on those close to home: Witchcraft violence in a Papua New Guinea village." The Australian Journal of Anthropology 25 (3): 267-286.

Kirsch, Stuart. 2014. Mining Capitalism: The Relationship between Corporations and Their Critics. Berkeley: University of California Press.

Lattas, Andrew, and Knut Rio. 2011. "Securing Modernity: Towards and Ethnography of Power in Contemporary Melanesia." Oceania 81 (1): 1-19.

Lindenbaum, Shirley. 1979. Kuru Sorcery: Disease and Danger in the New Guinea Highlands. Palo Alto: Mayfield Publishing.

Lindenbaum, Shirley. 2002. "Fore Narratives Through Time: How a Bush Spirit Became a Robber, Was Sent to Jail, Emerged as the Symbol of the Eastern Highlands Province, and Never Left Home." Current Anthropology 43 (S4): S63-S73.

Meyer, Birgit. 1999. Translating the Devil: Religion and Modernity among the Ewe in Ghana. Edinburgh: Edinburgh University Press.

Munn, Nancy. 1992 [1986]. The Fame of Gawa. Durham: Duke University Press.

Newell, Sasha. 2007. "Pentecostal Witchcraft: Neoliberal Possession and Demonic Discourse in Ivoirian Pentecostal Churches." Journal of Religion in Africa 37 (4): 461-490.

Newland, Lynda, and Terry Brown. 2015. "Introduction: Descent from Israel and Jewish Identities in the Pacific, Past and Present." Oceania 85 (3): 251-255.

Newman, Philip. 1964. "Religious Belief and Ritual in a New Guinea Society." American Anthropologist 66: 257-271.

Newman, Philip. 1965. Knowing the Gururumba. New York: Holt, Rinehart and Winston.

Read, Kenneth. 1952. "Nama Cult of the Central Highlands, New Guinea." Oceania 23: 1-25.

Read, Kenneth. 1955. "Morality and the Concept of the Person among the Gahuku-Gama.” Oceania 25: 233-282. 
Robbins, Joel. 2004a. Becoming sinners: Christianity and moral torment in a Papua New Guinea society. Berkeley: University of California Press.

Robbins, Joel. 2004b. "The globalization of Pentecostal and Charismatic Christianity." Annual Review of Anthropology 33: 117-143.

Schram, Ryan. 2010. "Witches' Wealth: Witchcraft, confession, and Christianity in Auhelawa, Papua New Guinea." Journal of the Royal Anthropological Institute 16 (4): 726-742.

Schram, Ryan. 2014. A New Government Breaks With The Past in The Papua New Guinea Parliament's "Haus Tambaran.” Material World, February. http://www.materialworldblog.com/2014/02/a-new-government-breakswith-the-past-in-the-papua-new-guinea-parliaments-haus-tambaran/.

Smith, R. M. 1979. "Christ, Keysser and Culture: Lutheran Evangelistic Policy and Practice in the Highlands of Papua New Guinea." Canberra Anthropology 2 (1): 78-97.

Stephen, Michelle. 1987a. "Contrasting images of power." In Sorcerer and Witch in Melanesia, ed. Michelle Stephen, 249-304. New Brunswick: Rutgers University Press.

Stephen, Michelle. 1987b. "Introduction." In Sorcerer and Witch in Melanesia, ed. Michelle Stephen, 1-14. New Brunswick: Rutgers University Press.

Strange, Gladys. 1965. "Nominal Elements in Upper Asaro." Anthropological Linguistics 7 (5): 71-79.

Strathern, Andrew. 1975. The Rope of Moka: Big-Men and Ceremonial Exchange in Mount Hagen New Guinea. Cambridge: Cambridge University Press.

Strathern, Marilyn. 1979. "The Self in Self-Decoration.” Oceania 49 (4): 241-257.

Strathern, Marilyn. 2013. Learning to See in Melanesia. Manchester: HAU Society for Ethnographic Theory.

Street, Alice. 2010. "Belief as relational action: Christianity and cultural change in Papua New Guinea." Journal of the Royal Anthropological Institute 16 (2): 260-278.

Strong, Thomas. 2006. "Land and Life: Some Terrains of Sovereignty in the Papua New Guinea Highlands." Suomen Antropologi 31 (3-4): 37-52.

Strong, Thomas. 2007. “'Dying Culture' and Decaying Bodies.” In Embodying Modernity and Post-Modernity in Melanesia, ed. Sandra Bamford, 105-123. Durham: Carolina Academic Press.

Tuzin, Donald. 1997. The Cassowary's Revenge: The Life and Death of Masculinity in a New Guinea Society. Chicago: University of Chicago Press.

Wesch, Michael. 2007. "A Witch Hunt in New Guinea: Anthropology on Trial." Anthropology and Humanism 32 (1): 4-17. 


\section{Author Biography}

Thomas Strong is a lecturer in the Department of Anthropology at Maynooth University in Ireland. He was educated at Reed College (BA) and Princeton University (Ph.D.). He is currently completing a monograph on witchcraft, violence, and modernity in highland Papua New Guinea, where he first began fieldwork in 1998.

Open Access This chapter is licensed under the terms of the Creative Commons Attribution 4.0 International License (http://creativecommons.org/licenses/ by $/ 4.0 /)$, which permits use, sharing, adaptation, distribution and reproduction in any medium or format, as long as you give appropriate credit to the original author(s) and the source, provide a link to the Creative Commons license and indicate if changes were made.

The images or other third party material in this chapter are included in the chapter Creative Commons license, unless indicated otherwise in a credit line to the material. If material is not included in the chapter Creative Commons license and your intended use is not permitted by statutory regulation or exceeds the permitted use, you will need to obtain permission directly from the copyright holder.

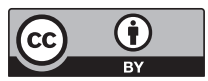

